\title{
Changes in soil organic carbon contents and fractionations of forests along a climatic gradient in China
}

\author{
Xiaolu Sun ${ }^{1,2} \mathbb{D}$, Zuoxin Tang ${ }^{1,2}$, Michael G. Ryan ${ }^{3,4}$, Yeming You ${ }^{5}$ and Osbert Jianxin Sun ${ }^{1,2^{*}}$
}

\begin{abstract}
Background: Soil organic carbon (SOC) is a large reservoir of terrestrial carbon (C); it consists of different fractions of varying complexity and stability. Partitioning SOC into different pools of decomposability help better predict the trend of changes in SOC dynamics under climate change. Information on how physical fractions and chemical structures of SOC are related to climate and vegetation types is essential for spatial modelling of SOC processes and responses to global change factors.
\end{abstract}

Method: Soil samples were collected from multiple representative forest sites of three contrasting climatic zones (i.e. cool temperate, warm temperate, and subtropical) in eastern China. Measurements were made on SOC contents and physical fractions of the $0-20 \mathrm{~cm}$ soil layer, and the chemical composition of SOC of the $0-5 \mathrm{~cm}$ soil layer, along with measurements and compilation of the basic site and forest stand variables. The long-term effects of temperature, litter inputs, soil characteristics and vegetation type on the SOC contents and factions were examined by means of "space for time substitution" approach and statistical analysis.

Result: Mean annual temperature (MAT) varied from $2.1^{\circ} \mathrm{C}$ at the cool temperate sites to $20.8^{\circ} \mathrm{C}$ at the subtropical sites. Total SOC of the $0-20 \mathrm{~cm}$ soil layer decreased with increasing MAT, ranging from $89.2 \mathrm{~g}^{\circ} \mathrm{kg}^{-1}$ in cool temperate forests to $57.7 \mathrm{~g}_{\mathrm{kg}}{ }^{-1}$ in subtropical forests, at an average rate of $1.87 \%$ reduction in SOC with a $1{ }^{\circ} \mathrm{C}$ increase in MAT. With increasing MAT, the proportions of aromatic $C$ and phenolic $C$ displayed a tendency of decreases, whereas the proportion of alkyl $\mathrm{C}$ and A/O-A value (the ratio of alkyl $\mathrm{C}$ to the sum of O-alkyl C and acetal C) displayed a tendency of increases. Overall, there were no significant changes with MAT and forest type in either the physical fractions or the chemical composition. Based on the relationship between the SOC content and MAT, we estimate that SOC in the top 20 soil layer of forests potentially contribute $6.58-26.3 \mathrm{Pg} \mathrm{C}$ globally to the atmosphere if global MAT increases by $1{ }^{\circ} \mathrm{C}-4^{\circ} \mathrm{C}$ by the end of the twenty-first century, with nearly half of which (cf. 2.87-11.5 Pg C) occurring in the $0-5 \mathrm{~cm}$ mineral soils.

Conclusion: Forest topsoil SOC content decreased and became chemically more recalcitrant with increasing MAT, without apparent changes in the physical fractions of SOC.

Keywords: Carbon fractions, Forest soil, Global warming, Solid-state ${ }^{13} \mathrm{C}$-CPMAS NMR

\footnotetext{
* Correspondence: sunjianx@bjfu.edu.cn

${ }^{1}$ College of Forest Science, Beijing Forestry University, Beijing 100083, China

${ }^{2}$ Institute of Forestry and Climate Change Research, Beijing Forestry

University, Beijing 100083, China

Full list of author information is available at the end of the article
} 


\section{Background}

Changes in soil organic carbon (SOC) with climatic factors and vegetation have been a subject of broad interest in assessing the impact of global change on ecosystem $\mathrm{C}$ balance and in devising management strategies for sequestrating carbon dioxide $\left(\mathrm{CO}_{2}\right)$ using natural systems. Soil stores about three quarters of the organic carbon contained in terrestrial ecosystems, and climate-driven changes to this pool could have a large impact on atmospheric $\mathrm{CO}_{2}(\mathrm{Smith}$ et al. 2008; Stockmann et al. 2013). The fact that some portions of the SOC pool can persist for millennia while others decompose readily can obscure our understanding of the mechanisms controlling the SOC storage (Lützow et al. 2007; Schmidt et al. 2011). Previous studies have indicated that both biochemical resistance and physicochemical protection contribute to differences in decomposability of SOC (see reviews by Lützow et al. 2007; Schmidt et al. 2011). Partitioning SOC into different pools of decomposability could help better predict the dynamics of SOC under climate change (Lützow et al. 2007; Kleber 2010). However, little information is available on how physical fractions and the chemical structures of SOC are related to climate and vegetation types, especially for forest soil, which makes up 39\% of global soil carbon storage (Watson et al. 2000).

SOC is commonly partitioned into three fractions differing in decomposability and protection mechanisms: active or labile, intermediate or slow, and stable or passive (Sollins et al. 1996; Mayer 2004; Lützow et al. 2006; Schmidt et al. 2011) (Fig. 1). Chemically, the active fractions refer to labile SOC consisting of hydrolysable chemical bonds of saccharides, proteins and their decomposed products; the stable fraction is usually made up of recalcitrant SOC compounds including aromatic or other macromolecules derived from lignin, lipids, waxes, suberins, cutins and pyrogenic organic carbon from thermal degradation (Derenne and Largeau 2001; Lützow et al. 2006; Knicker 2011; Paul 2016). Solid-state ${ }^{13} \mathrm{C}$ cross polarization nuclear magnetic resonance (CP-MAS NMR) spectroscopy can determine the chemical composition of SOC by quantifying the distribution of different carbon compounds and allow comparisons of decomposability among soil samples (Kögel-Knabner 1997; Conte et al. 2002; Pisani et al. 2014). Physically, stable SOC is protected by bonding to soil mineral particles by ligand exchange, polyvalent cation bridges, Van der Waals forces, and H-bonding etc. (Jastrow and Miller 1997; Six et al. 2002a; Eusterhues et al. 2003; Lützow et al. 2006; Dungait et al. 2012); the intermediate or slow SOC is the occluded particle organic matter (POM) which is isolated by aggregation formation (Christensen 2001; Six et al. 2002b, 2004; Lützow et al. 2006; Gupta and Germida 2015); and the active SOC is non-protected and its decomposability is considered to be determined by chemical structures (Sollins et al. 1996; Mayer 2004; Lützow et al. 2006;

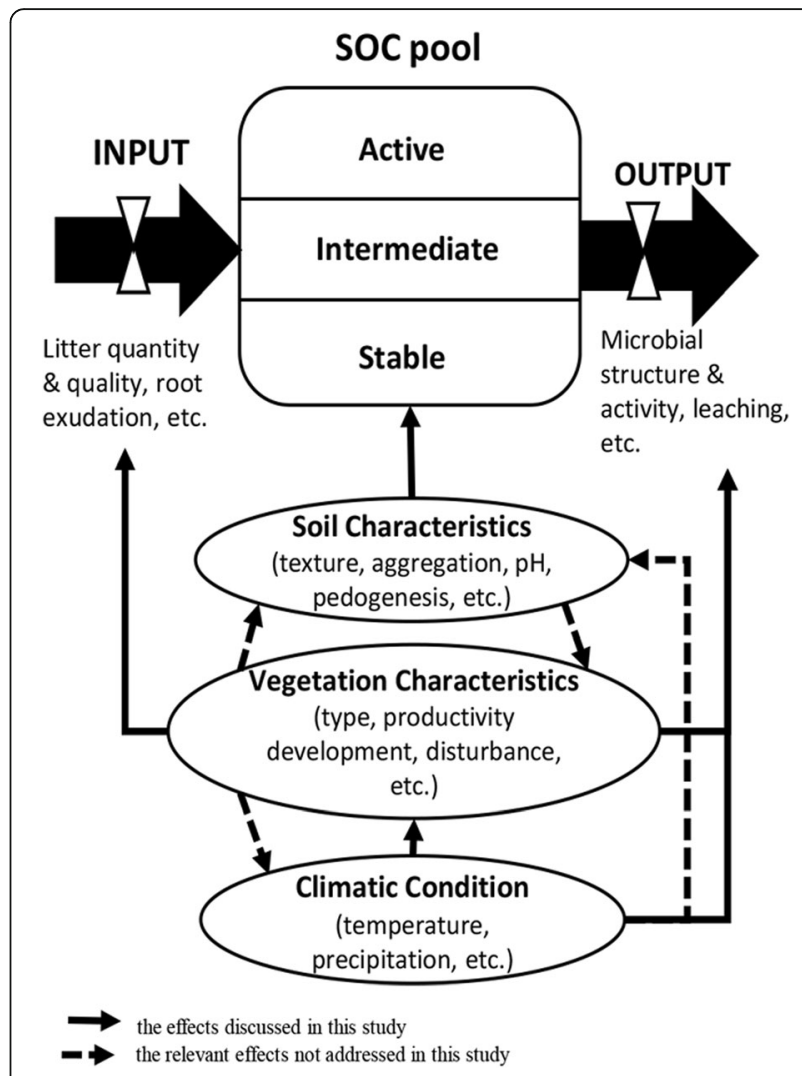

Fig. 1 Conceptual diagram illustrating how climate, vegetation, and soil characteristics affect SOC pools in forest ecosystems

Schmidt et al. 2011). The protection occurs in ways of blockage of microbial access and reduced diffusion of enzyme and oxygen into the intro-aggregate space (see review by Lützow et al. 2006). Fractionation of SOC can identify the type of physical protection (Golchin et al. 1994; Six et al. 2002a, 2002b, 2004; Lützow et al. 2007; Paul 2016). Previous studies have shown that SOC associated with clay and silt has older age or longer turnover time than the non-protected SOC (Chenu and Stotzky 2002; Eusterhues et al. 2003; Lützow et al. 2006; Wagai et al. 2009).

Many factors can affect SOC stocks and composition. Climate affects forest SOC by shaping both SOC input (changing plant productivity) and output (affecting soil microbial and faunal metabolism) (Fig. 1); the overall response of SOC to climate change depends on the balance between these two processes (Smith et al. 2008; Stockmann et al. 2013). However, most researches on responses of SOC to warming have primarily focused on decomposition, neglecting the SOC input (Bradford et al. 2016). How and to what extent climate regulates forest SOC fractions and chemical structures are still under debate. There are believes that, as mean annual temperature (MAT) rises, the labile forest SOC is more easily decomposed and the recalcitrant SOC components tend to accumulate, making the SOC pool overall 
more resistant to decomposition (Garten and Hanson 2006; Fissore et al. 2008; Garten 2011; Du et al. 2014; Pisani et al. 2014; Tian et al. 2016). Some are of the view that the recalcitrant forms of SOC would have similar sensitivity or are more sensitive to temperature than the labile forms (Fierer et al. 2005; Fang et al. 2005; Conen et al. 2006). The contrasting views might arise by considering the temperature sensitivity based on decomposition of compounds versus that inferred from pool behavior. Temperature sensitivity of decomposition reactions does increase with the compound complexity, much of the recalcitrant pool is physically protected from decomposition (Davidson and Janssens 2006; Conant et al. 2011), yielding little or no change of SOC in response to MAT (Giardina and Ryan 2000).

Vegetation affects the SOC pool size through differential quantity and quality of organic matter inputs and modification of soil microbial community composition (Quideau et al. 2001; Stockmann et al. 2013; You et al. 2014; Castellano et al. 2015) (Fig. 1). Although it is generally believed that the physio-chemical protection, not the initial chemical composition, may be the dominant factor controlling SOC decomposition (Lützow et al. 2007; Schmidt et al. 2011), litter quality can affect SOC stabilization by affecting the microbial processes in the initial decomposition stage (Prescott et al. 2000; Pisani et al. 2013; Castellano et al. 2015; Wang et al. 2015, 2016; Zhang and Zhou 2018). Vegetation community structure may also affect SOC pool size by altering both micro-environment and soil characteristics (You et al. 2014).

Soil characteristics such as mineral type, $\mathrm{pH}$ and texture can affect SOC composition. Soil mineralogy alters the chemical protection of SOC by controlling the number and type of chemical bonds formed with organic carbon (Lützow et al. 2006; Jones and Singh 2014; Johnson et al. 2015; Paul 2016). In acidic soil, mineral particles with Fe, $\mathrm{Al}$ and $\mathrm{Mn}$ oxides bind with organic carbon through ligand exchange, protecting the SOC from decomposition (Mikutta et al. 2006; Kögel-knabner et al. 2008; Jones and Singh 2014). Binding of SOC (usually the alky-C) with clay particles usually leads to a longer mean residence time (MRT) compared to SOC binding with larger soil particles (Lützow et al. 2006; Paul 2016). However, there are research findings indicating that soil characteristics would also be affected by climate (Mathieu et al. 2015), and soil $\mathrm{pH}$ and cation exchange capacity (CEC) may both decline with increasing MAT (Fissore et al. 2008).

Here we compared the physical fractionations and chemical composition of SOC in the $0-20 \mathrm{~cm}$ layer of the mineral soil in eight wet forests for three climatic zones in China to address three questions: 1) In forests rarely experiencing soil water deficit, does SOC and its physical and chemical fractions vary across forest sites differing in MAT? 2) Can any pattern of SOC and its fractions with temperature across sites be isolated solely to temperature, or do other factors, such as vegetation type, organic matter inputs or soil texture, help determine the pattern? 3) Can the patterns of SOC and its physical or chemical fractions with MAT suggest how SOC might change with climate warming? We hypothesized that: 1) as SOC decomposition is predominantly a microbial-driven process, increases in temperature would facilitate soil microbial activities and the kinetics of soil extracellular enzymes, thereby causing declines in forest SOC stocks along the gradient of increasing MAT (Davidson and Janssens 2006; Conant et al. 2011; Stockmann et al. 2013); and 2) because of the differences in physical protection and/or chemical recalcitrance, changes in MAT of the study sites would lead to differential partitioning of SOC fractions such that the higher MAT sites would have greater proportions of physically protected SOC fractions and C compounds of greater chemical stability compared with the lower MAT sites.

\section{Materials and methods Study sites}

Our study sites extend across three distinct climatic zones in China, including the Dinghu Mountains National Nature Reserve $\left(23.09^{\circ} \mathrm{N}, 111.30^{\circ} \mathrm{E}\right)$ of subtropical climate (MAT of $20.8^{\circ} \mathrm{C}$, mean annual precipitation (MAP) of $1990 \mathrm{~mm}$ ), the Baotianman National Nature Reserve $\left(33.20^{\circ} \mathrm{N}, 111.46^{\circ} \mathrm{E}\right)$ of warm temperate climate (MAT of $15.1^{\circ} \mathrm{C}$, MAP of 855 $\mathrm{mm}$ ), and the Changbai Mountains National Nature Reserve $\left(41.41^{\circ} \mathrm{N}, 127.42^{\circ} \mathrm{E}\right)$ of cool temperate climate (MAT of $2.1^{\circ} \mathrm{C}$, MAP of $740 \mathrm{~mm}$ ) (Table 1). These sites belong to Chinese humid zones (Zhao et al., 2010), and rarely experience soil water deficit.

The subtropical site has three forest communities: a mature monsoon evergreen broadleaved forest protected from anthropogenic disturbance for more than 400 years with an overstory dominated by Castanopsis chinensis, Schima superba and Cryptocarya chinensis, a mixed pine-broadleaved forest existed for 60 years and originated from a planted Pinus massoniana that was naturally colonized by broadleaf species, and a conifer forest of Pinus massoniana (Zhou et al. 2005; Zhang et al. 2013). The warm temperate site has both natural deciduous broadleaved forests dominated by Quercus aliena, and mixed forests of Quercus aliena and Pinus armandii that developed from plantations established around 1956 (You et al. 2014, 2016; Wang et al. 2015). The cool temperate sites contains coniferous forests with Picea jezoensis, Abies nephrolepis and Larix olgensis in the overstory, mixed conifer broadleaved forests with Pinus koraiensis, Tilia amurensis, Acer mono, and Fraxinus mandshuric in the overstory, and broadleaf forests that regenerated after logging in the Pinus koraiensis forests, commonly with an overstory of Betula platyphylla and Populus davidiana (Wang et al. 2004; Liu et al. 2009; Yang et al. 2010). 


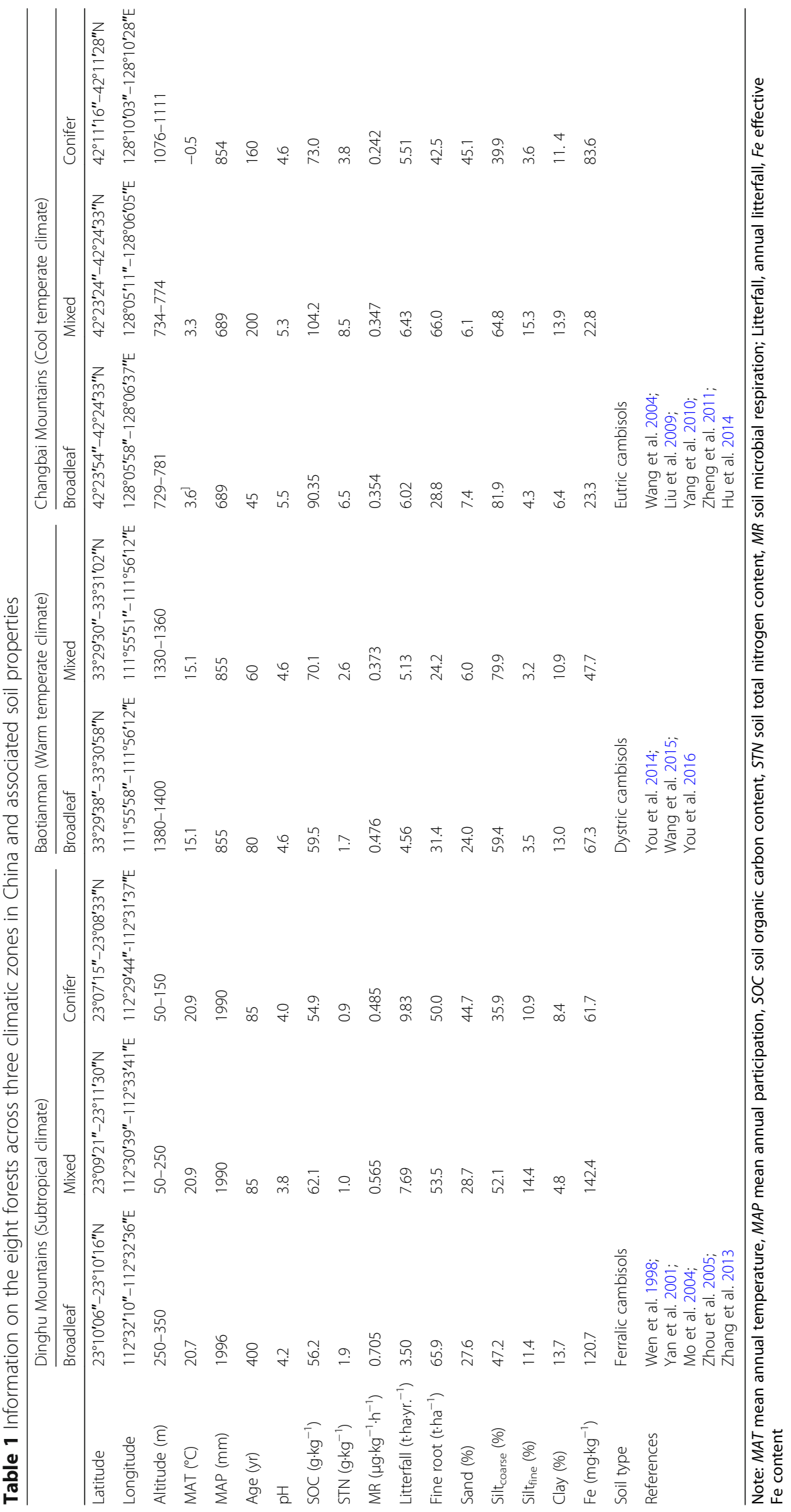


Climate and soils of the eight representative forests are described in Table 1 . Five $20 \mathrm{~m} \times 20 \mathrm{~m}$ plots were established and sampled for each forest type within each climatic zone. The plot locations were determined within a representative forest stand and kept at least $0.5 \mathrm{~km}$ apart from each other. The soil effective Fe content was extracted by $50 \mathrm{~mL} 0.1 \mathrm{M} \mathrm{HCl}$ in of $10 \mathrm{~g}$ soil sample and tested by inductively coupled plasma atomic emission spectrometry (ICP-AES) (ICAP-9000, Jarrell-Ash, USA), and soil texture was identified by wet sieve (to separate sand fraction) and centrifugation (to separate clay and slit fraction). We also conducted literature search and collected published data required in our study.

\section{Soil sampling}

Soil samples were collected once from five plots in each of the eight forest ecosystems across the three climatic zones from May to June of 2013. In each plot, twenty-four soil cores of $0-5,5-10$ and $10-20 \mathrm{~cm}$ mineral soil layers were collected with a stainless-steel soil sampler (3-cm innerdiameter) following an "S" path. Individual soil cores from the same plot were mixed to form a single composite sample, sieved to pass a 2-mm mesh, and air dried.

\section{Physical fractionation of SOC}

To better understand how soil stabilization differed with site (climate) and forest type, we partitioned the SOC pool into three physical fractions of organic carbon (OC): mineral (bound) OC, free $\mathrm{OC}$ and occluded OC (Golchin et al. 1994; Lützow et al. 2007). The mineral OC refers to the fraction of SOC bonded to soil silt and clay particles $(<53 \mu \mathrm{m})$, and represents the most stable component of SOC. The mineral OC was estimated by dispersion with $50 \mathrm{~mL}$ of $6 \% \mathrm{H}_{2} \mathrm{O}_{2}$ and $50 \mathrm{~mL}$ of $0.5 \mathrm{~mol} \cdot \mathrm{L}^{-1} \mathrm{NaOH}$ and filtration by a $53 \mu \mathrm{m}$ filter (Mikutta et al. 2005). The residue passing through the filter was collected as the mineral-bound SOC, dried at $40^{\circ} \mathrm{C}$ and weighed. The free $\mathrm{OC}$ is the light fraction of SOC, which occurs as the most labile carbon pool. The free OC fraction was determined by density fractionation with sodium iodide at a density $<1.6 \mathrm{~g} \cdot \mathrm{cm}^{-3}(\mathrm{NaI})$ (Sollins et al. 2006). The suspended material (density < $1.6 \mathrm{~g} \cdot \mathrm{cm}^{-3}$ fraction) was filtered under suction and the filter residue was collected, dried at $40^{\circ} \mathrm{C}$, and weighed to estimate the free OC. The occluded OC is the fraction of SOC protected in soil aggregates, calculated as the difference between the total SOC and the sum of free $\mathrm{OC}$ and mineral $\mathrm{OC}$, and represents the SOC of intermediate decomposability.

The $\mathrm{C}$ content for the free $\mathrm{OC}$, the mineral $\mathrm{OC}$, and the original soil samples were analyzed by the $\mathrm{K}_{2} \mathrm{Cr}_{2} \mathrm{O}_{7}-\mathrm{H}_{2} \mathrm{SO}_{4}$ calefaction method (Nelson and Sommers 1982).

\section{SOC chemical composition}

Solid-state ${ }^{13} \mathrm{C}$ CPMAS NMR was used to determine the chemical composition of SOC in the $0-5 \mathrm{~cm}$ soil layer, as this layer had the highest SOC content. The NMR spectra were obtained at a frequency of $100.38 \mathrm{MHz}$ on a Bruker Avance III $400 \mathrm{M}$ with a $4 \mathrm{~mm}$ MAS probe (Bruker Avance III 400 M, Bruker, Switzerland). To reduce the paramagnetic material and increase the organic matter content, $50 \mathrm{~mL}$ of $10 \%$ hydrofluoric acid (HF) was added to $5 \mathrm{~g}$ soil sample, the suspension was shaken for one hour, centrifuged for $10 \mathrm{~min}$ at $3000 \mathrm{rpm} \cdot \mathrm{min}^{-1}$, and the supernatant discarded, this procedure was repeated eight times, and the precipitate was then washed four times by distilled water and dried at $40{ }^{\circ} \mathrm{C}$ (Schmidt et al. 1997). In the ${ }^{13} \mathrm{C}$ CPMAS NMR operations, this HF-pretreated soil sample material was spun at $5 \mathrm{kHz}$ in a $\mathrm{ZrO}_{2}$ rotor (o.d. $=4 \mathrm{~mm}$ ) at the magic angle with a contact time of $3 \mathrm{~ms}$ and a recycle delay time of $1 \mathrm{~s}$. The chemical shift reference was glycine (176.03 ppm). Spinning side-bands were eliminated using the total suppression of side bands (TOSS) sequence.

The ${ }^{13} \mathrm{C}$ CPMAS NMR spectra were plotted between -100 and $300 \mathrm{ppm}$, and spectra were divided into six chemical shift regions representing alkyl C (10-45 ppm), O-alkyl C (45-90 ppm), acetal C (90-110 ppm), aromatic C (110-140 ppm), phenolic C (140-160 ppm), and carboxyl C (160-200 ppm; Baldock et al. 1990). The labels assigned to each region are considered to be only indicative of the dominant $C$ type present. The total signal intensity and the proportion contributed by each $\mathrm{C}$ type were determined by integration of spectral regions. Alkyl C (10-45 ppm) is commonly derived from long-chain lipids and aliphatic biopolymers, such as suberin, cutin and resin, and it is considered to be the most stable part of SOC (Skjemstad et al. 1983; Oades 1995; Kögel-Knabner 1997; Krull and Skjemstad 2003). O-alkyl C (45-90 ppm) generally consists of proteinaceous structures and secondary alcohols, and acetal C (90-110 ppm) represents deoxygenated (anomeric) polysaccharides. Both are derived from cellulose and other carbohydrate decomposition and are readily decomposed (Baldock et al. 1990; Krull and Skjemstad 2003). The aromatic (110-140 ppm) and phenolic (140-160 ppm) regions are derived from lignin, tannins and charcoal, and are difficult to decompose (Skjemstad and Dalal 1987; Skjemstad et al. 1996; Krull and Skjemstad 2003). Carbonyl C (160-200 ppm) typically consists of amides, carboxylic acids and esters which can be readily decomposed (Baldock et al. 1990; Krull and Skjemstad 2003). We calculated the ratio of alkyl C to the sum of O-alkyl C and acetal C (A/ $\mathrm{O}-\mathrm{A})$ as an index of the decomposition state of SOC; and high values of $\mathrm{A} / \mathrm{O}-\mathrm{A}$ represent highly decomposed SOC; this index is positively correlated to SOC stability (Wang et al. 2010; Du et al. 2014). 


\section{Statistical analyses}

Because site was confounded with climate, we considered the different site-vegetation-types $(n=8)$ as the sample unit for testing the effects of MAT and vegetation type on the total SOC, chemical composition and physical fractions with ANOVA. If significant ANOVA differences were present for the effect of MAT, we used an orthogonal polynomial contrast to test for a linear pattern. All data were analyzed using SPSS Version 19.0 with $\alpha<0.05$ for accepting significance, unless otherwise specified.

\section{Results}

\section{Site and soil characteristics}

MAP for the past 20 years varied from 690 to $850 \mathrm{~mm}$ at the coolest site to about $2000 \mathrm{~mm}$ at the warmest site (Table 1). SOC concentration of the mineral soil in the $0-20 \mathrm{~cm}$ layer varied across sites and vegetation types, ranging from 54.9 to $104.2 \mathrm{~g} \cdot \mathrm{kg}^{-1}$, and total soil $\mathrm{N}$ was highly correlated with SOC $(r=0.97)$. Soils were mostly silt (65\% averaged across sites), with the sand fraction varying from $6.1 \%$ to $45.1 \%$ and the clay fraction varying from $4.8 \%$ to $13.7 \%$ across sites (Table 1 ).

\section{Variations of the total SOC and fractions with mean annual temperature (MAT)}

The total SOC concentration in the mineral soil of the $0-20 \mathrm{~cm}$ layer differed among locations $(p=0.04)$ and had a negative linear relationship with MAT $(p=0.01$; Fig. 2a). The value of total SOC concentration was 57.7 $\mathrm{g} \cdot \mathrm{kg}^{-1}$ at the warmest site, 35\% lower than the SOC concentration of $89.2 \mathrm{~g} \cdot \mathrm{kg}^{-1}$ at the coolest site. A linear fit to the MAT gradient gave an average rate of reduction in the total SOC of $1.87 \%$ with $1{ }^{\circ} \mathrm{C}$ increase in MAT. All three physical fractions of total SOC trended lower as MAT increased $(32 \%-41 \%$ lower in the warmest sites versus the coolest sites; Fig. 2a), but differences among the sites of different climates were not significant $(p>$ 0.06 ); fraction composition as percentage of total SOC did not differ among sites $(p>0.76)$. When pooling the data for all the forest sites $(n=8)$, SOC and all its three physical fractions had significantly negative linear relationships with MAT $(p<0.01)$.

Among the three subdivided soil layers, only the $0-5 \mathrm{~cm}$ layer displayed a significant decrease $(p=0.01$; Fig. $2 \mathrm{~b})$ in the total SOC with increasing MAT, at an average rate of $2.91 \%$ reduction with a $1{ }^{\circ} \mathrm{C}$ increase in MAT. The physical fractionations of the different soil layers did not vary across sites, except for the occluded OC in the $10-20 \mathrm{~cm}$ layer being highest at the sites with MAT of $15.1^{\circ} \mathrm{C}(p=$ 0.046; Fig. 2d).

The chemical composition of $0-5 \mathrm{~cm}$ SOC, inferred by the proportion of each chemical fraction in total SOC, did not differ among forest types $(p>0.26)$ or vary with MAT (Figs. 3 and 4). SOC was mostly composed of O-alkyl C $($ mean $=32 \%)$ and alkyl $C$ groups $($ mean $=26 \%)$, followed by aromatic and carbonyl C (mean $=13 \%$ both), acetal C (mean $=9 \%)$, and phenolic $\mathrm{C}($ mean $=8 \%)$. The percentages of aromatic $\mathrm{C}$ and phenolic $\mathrm{C}$ have a tendency of decreases with MAT, while the percentage of alkyl $C$ and the value of A/O-A showed a tendency of insignificant increases $(p>$ 0.13, Fig. 5). When pooling the data for all the forest sites $(n=8)$, alkyl $\mathrm{C}$ and $\mathrm{A} / \mathrm{O}-\mathrm{A}$ value had significantly negative
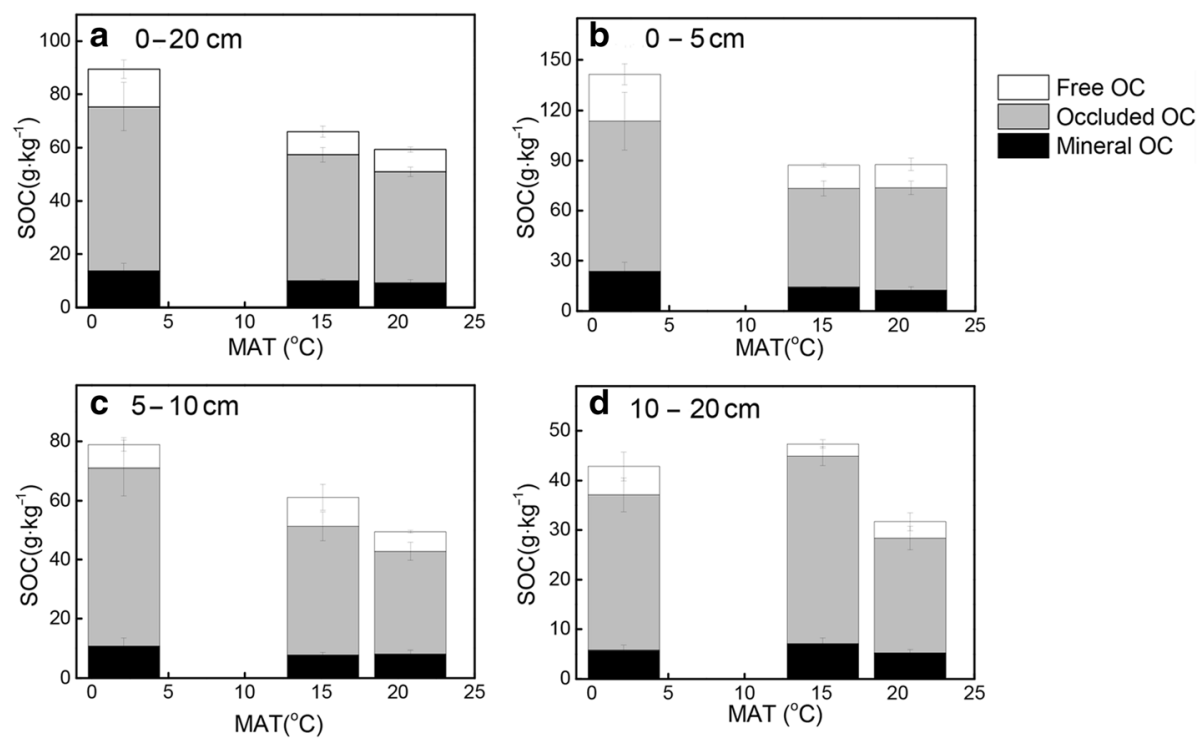

Fig. 2 Variations in the concentrations of total SOC and physical fractions with MAT. a 0-20 cm layer; (b) $0-5 \mathrm{~cm}$ layer; (c) $5-10 \mathrm{~cm}$ layer; and (d) 10-20 cm layer. Values are averages across forest types within climatic zones. Vertical bars indicate standard errors of means $(n=3$ for the cool temperate and subtropical sites, and 2 for the warm temperate sites) 


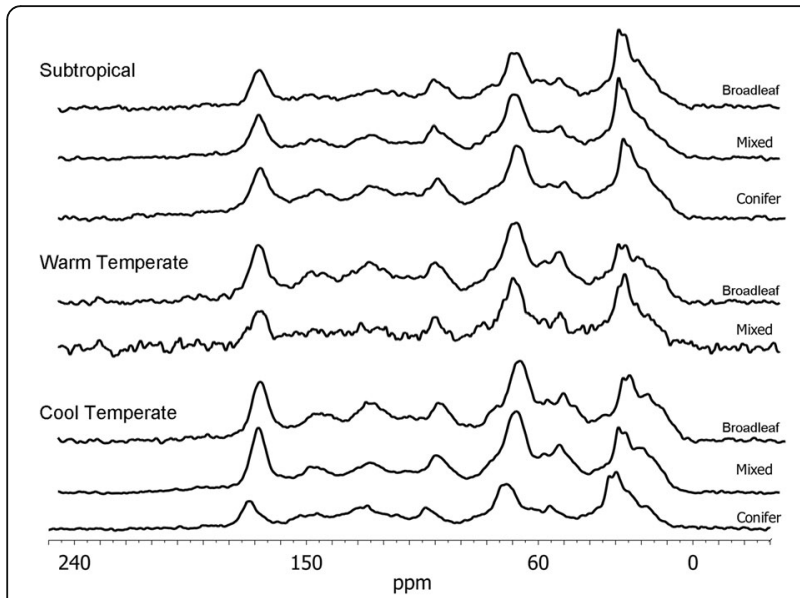

Fig. $3{ }^{13} \mathrm{C}$ NMR spectrum of $0-5 \mathrm{~cm}$ soil layer across eight forest sites in three climatic zones

linear relationships with MAT $(p<0.05)$ and aromatic $C$ had a significantly positive relationship with MAT $(p<0.01)$.

\section{Are factors other than temperature important in the MAT response of SOC?}

Averaged across the sites of different climates, SOC concentration showed no apparent pattern with vegetation types. The total SOC concentration and the concentration of mineral $\mathrm{OC}$, free $\mathrm{OC}$ and occluded $\mathrm{OC}$ fractions did not differ among forest types for either the whole profile of $0-20 \mathrm{~cm}$ soil layer or the subdivided soil layers of $0-5,5-10$ and $10-20 \mathrm{~cm}(p>0.98$; Fig. 6).

The decreasing pattern in total SOC concentration with MAT across sites of different climates was accompanied by changes in the organic matter input (litter) and output (soil microbial respiration) and soil characteristics (effective Fe content). Both annual litterfall and soil microbial respiration increased with MAT (linear orthogonal contrast $p=0.01$ and 0.02 ; Fig. $7 \mathrm{a}$ and $\mathrm{b}$ ), evidence that a decrease in SOC concentration with MAT did not result from the changes in either organic matter input or output, but a balance between the input and the output.

The soil effective Fe content also increased with increasing MAT (linear orthogonal contrast $p=0.02$; Fig. 5 f), but soil clay content did not vary with MAT (linear orthogonal contrast $p>0.51$; Fig. 7c).

\section{Discussion}

There have been some on-going debates as what controls the decomposability of SOC. And results from previous studies demonstrated either declining forest SOC with increasing MAT (Bird et al. 2002; Garten and Hanson 2006; Raich et al. 2006; Fissore et al. 2008; Garten 2011) or no significant variations in the total SOC stocks with MAT (Trumbore et al. 1996; Giardina and Ryan 2000; Plante et al. 2006; Zimmermann et al. 2010). This contradiction might be due to that warmer climate often lend to increases in both plant productivity (SOC input) and soil respiration (SOC output), changes in the SOC stock with temperature are determined by the balance of SOC gain through increased productivity and SOC loss through soil respiration (Raich et al. 2006; Smith et al. 2008; Ziegler et al. 2017). Results in this study also show that the decreasing SOC with MAT is associated with increases in both annual litterfall and soil microbial respiration. So our findings of decreasing total SOC with increasing MAT suggest greater impacts of warming on accelerating SOC decomposition than on increasing SOC input in Chinese wet forests.

All physical fractions and chemical fractions of total SOC were not significantly different among the sites of different climates. However, when data were pooled for all the study sites, we found significant relationships in some of variables of the physical and chemical fractions

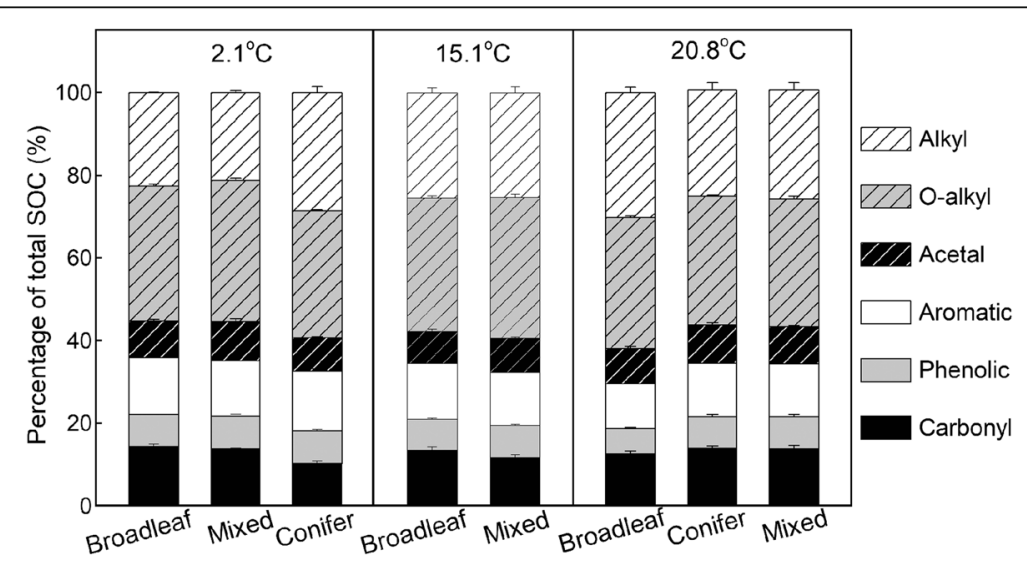

Fig. 4 Variations in the proportion of different chemical fractions across eight forests in three climatic zones. Values are averages of sampling plots for each forest type within climatic zones. Vertical bars indicate standard errors of means $(n=5)$ 

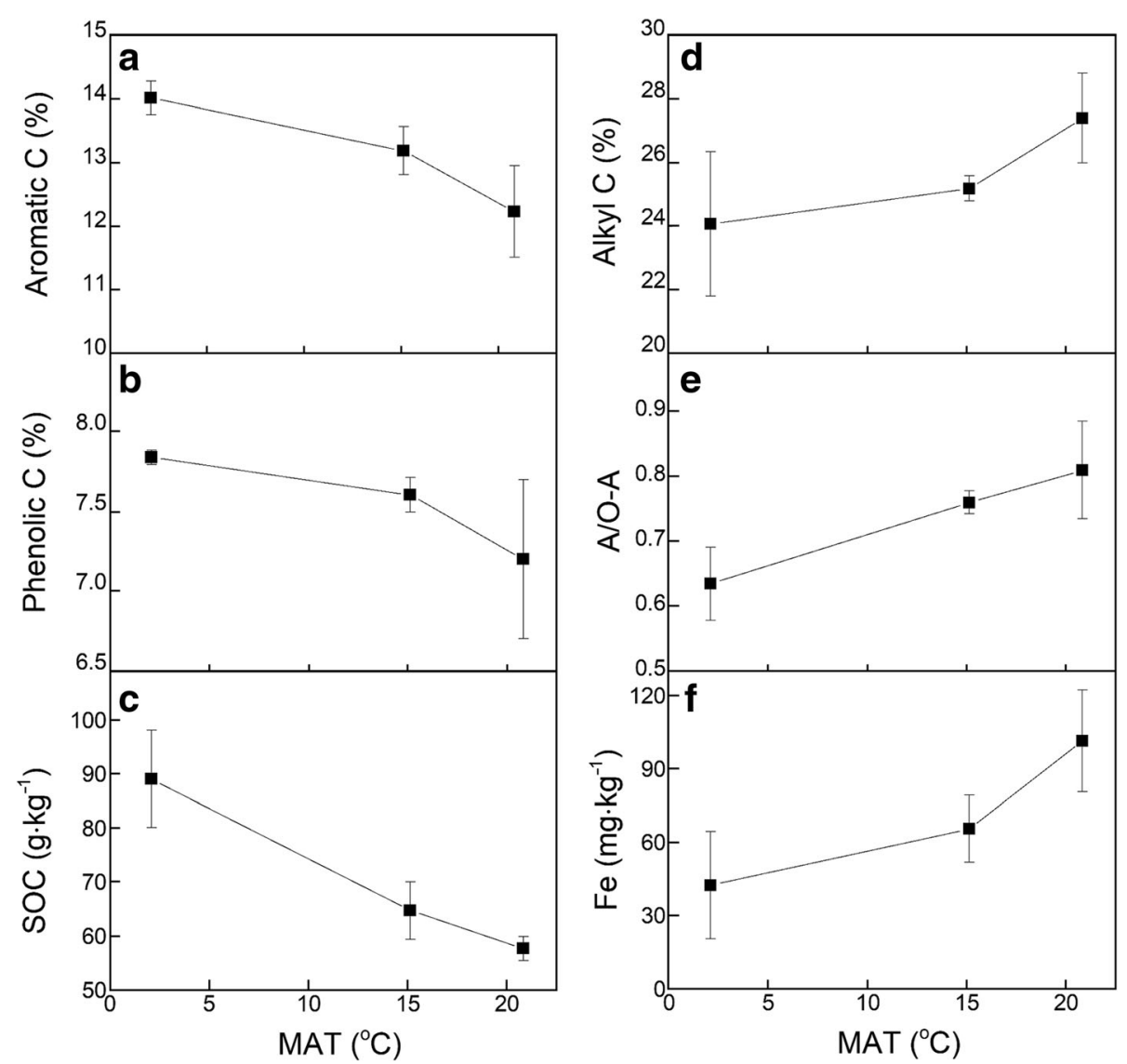

Fig. 5 Variations in (a) percentage of aromatic $C_{;}(\mathbf{b})$ percentage of phenolic $C_{;}(\mathbf{c})$ total SOC content; (d) percentage of alkyl $C_{;}(\mathbf{e})$ A/O-A value; and (f) effective Fe content with MAT. Values are averages across forest types within climatic zones. Vertical bars indicate standard errors of means ( $n=3$ for the cool temperate and subtropical sites, and 2 for the warm temperate sites)

with MAT, with inferences to increased proportion of physically and chemically more stable SOC with increasing MAT of the forest sites. With increasing MAT, the proportions of aromatic $\mathrm{C}$ and phenolic $\mathrm{C}$ had a tendency of decreases, whereas the proportion of alkyl $\mathrm{C}$ and $\mathrm{A} / \mathrm{O}-\mathrm{A}$ value trended higher. As aromatic $\mathrm{C}$ is intermediately decomposable and concentrated in the occluded $\mathrm{OC}$ pool, and alkyl $\mathrm{C}$ percentage and the $\mathrm{A} / \mathrm{O}-\mathrm{A}$ value are positively related to stable soil C (Skjemstad et al. 1983; Oades 1995; Kögel-Knabner 1997; Krull and Skjemstad 2003; Courtier-Murias et al. 2013; Du et al. 2014), our results suggest preferential preservation of $C$ compounds of higher stability with warmer climate. This is supported by findings from some recent studies (Garten and Hanson 2006; Fissore et al. 2008; Garten 2011; Du et al. 2014; Pisani et al. 2014; Tian et al. 2016). Findings largely vary in literature in the temperature response of SOC fractions. Garten (2011) reported that, in the top soil of five forest sites along a latitudinal gradient with MAT from $6.2{ }^{\circ} \mathrm{C}$ to $14.6{ }^{\circ} \mathrm{C}$ in North American, the labile POM content decreased by $26 \%$ with increasing MAT, but the mineral OC did not show a linear relationship with MAT. Fissore et al.
(2009) studied the subpools of SOC across 26 sites under hardwood or pine forests with MAT ranging from $-2{ }^{\circ} \mathrm{C}$ to $20^{\circ} \mathrm{C}$ in North America using incubation and chemical methods, and found that only the active SOC decreased strongly with increasing MAT, while slow and acid insoluble SOC showed no significant relationships with MAT. Hakkenberg et al. (2008) determined the turnover time of different SOC fractions in 11 forests along a MAT gradient from $4.2{ }^{\circ} \mathrm{C}$ to $11.8^{\circ} \mathrm{C}$, with findings that the turnover time of heavy and light fractions (stabilized and intermediate pools) decreased at about $8 \%-16 \%$ and $4 \%-$ $11 \%$, respectively, with a $1{ }^{\circ} \mathrm{C}$ increase in MAT. The inconsistency among studies in the relationship of the total SOC or its fractions with temperature may arise from complex mechanisms controlling SOC stocks and processes. The mechanisms of temperature response may vary with the type of SOC fractions. The free OC is physically unprotected and can be temperature sensitive as its enzyme-controlled decomposition increases at higher temperature (Davidson and Janssens 2006; Conant et al. 2011). In contrast, the response of mineral associated SOC to higher temperature may differ with mineral types and 

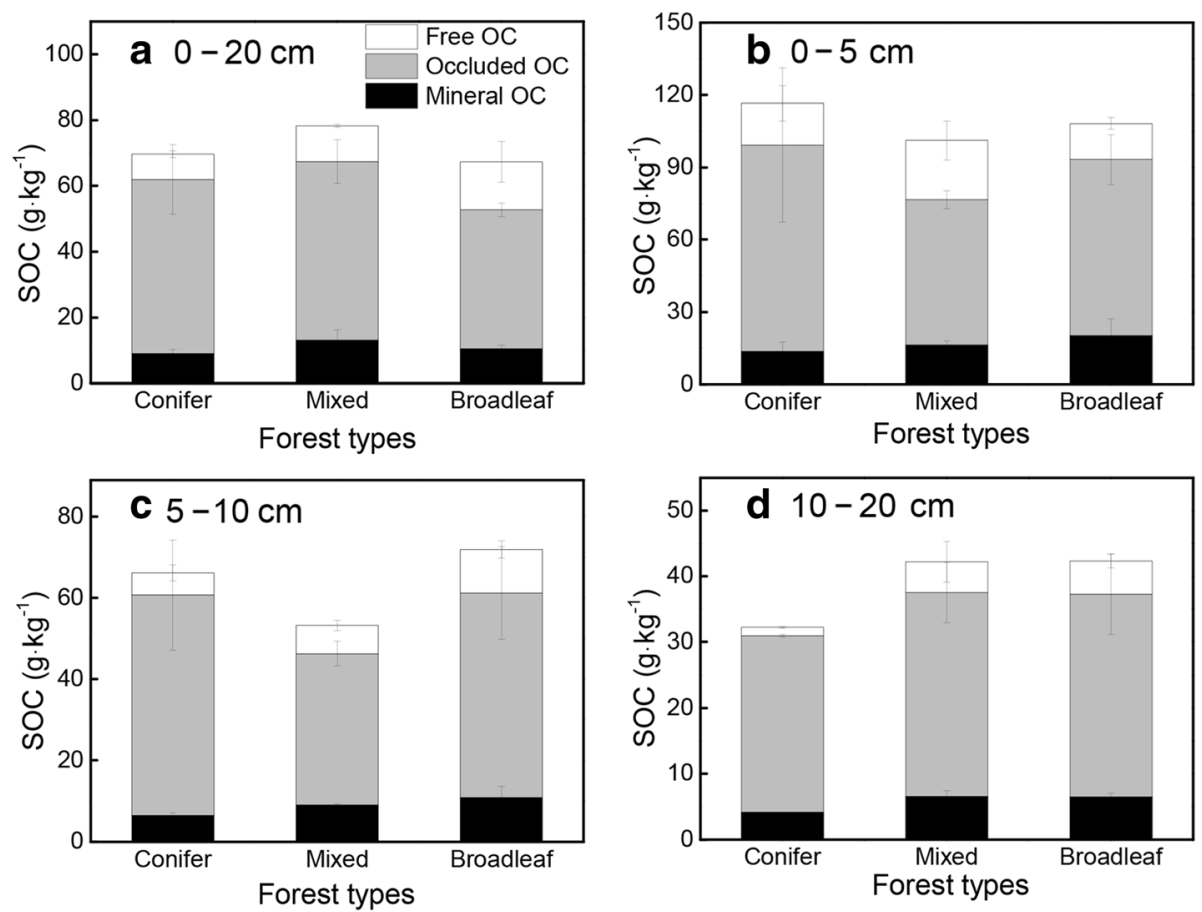

Fig. 6 Variations in the concentrations of total SOC and physical fractions among forest types. a 0-20 cm layer; (b) $0-5 \mathrm{~cm}$ layer; (c) $5-10 \mathrm{~cm}$ layer; (d) $10-20 \mathrm{~cm}$. Values are averages of the same forest types across climatic zones. Vertical bars indicate standard errors of means $(n=3$ for broadleaf and mixed forest, and 2 for conifer forest)

bond type (Conant et al. 2011). While several types of mineral-OC bonds would desorb with warmer temperatures, stronger ligand exchange bonding might also occur (ten Hulscher and Cornelissen 1996; Pignatello 1999; Conant et al. 2011). The mechanism of the temperature response in aggregated OC is unclear (Plante et al. 2009).

We found no apparent effects of forest type on the total SOC and its physical fractions and chemical groups. Among the soil variables studied, only the effective $\mathrm{Fe}$, which is often positively related to soil mineral OC (Mikutta et al. 2006; Kögel-Knabner et al. 2008; Jones and Singh 2014), displayed a similar trend with changes in the proportion of alkyl $\mathrm{C}$ and the A/O-A value with MAT. The soil clay content, which is commonly positive related with stable SOC (Lützow et al. 2006; Plante et al. 2006; Jones and Singh 2014), did not vary with MAT. Therefore, the declining SOC with increasing MAT is predominantly a temperature response.

In this study, the effects of vegetation and water limitation were controlled by including broadleaf forest, conifer forest and mixed-wood forest and restricting the study sites to humid regions. There possibly exist other confounding factors such as differences in soil types, pedology, and microbial communities resulting from geographical separations and long-term climatic influences. However, our laboratory testing indicated that SOC mineralization was mostly affected by initial soil substrate (Tang et al. 2018).
Matching laboratory-derived carbon fractions with the SOC models might better predict changes in SOC with climate (Motavalli et al. 1994; Smith et al. 2002; Poeplau et al. 2013). However, evidence for that contention is mixed. The current study did not reveal a clear and straightforward relationship between SOC composition and its temperature response. Therefore, the patterns of total SOC and its fractionations with MAT are insufficient in informing how SOC might change with climate warming. Integrating information of soil physiochemical properties, SOC fractionations and their interactions with decomposer communities could help to achieve a better understanding in SOC dynamics with changing environmental conditions (You et al. 2014, 2016).

Globally, forest soil stores about 704 Pg organic carbon (Lal 2005), about $50 \%$ of which is in the top $20 \mathrm{~cm}$ soil layer and $14 \%$ in the $0-5 \mathrm{~cm}$ mineral soil layer (Jobbágy and Jackson 2000). If the relationship for SOC found across sites with different MAT holds for other forested sites, we estimate that by end of the twenty-first century, the top $20 \mathrm{~cm}$ mineral soil $(1.87 \%$ reduction rate) in forests worldwide would contribute from $6.58 \mathrm{Pg} \mathrm{C}$ to the atmosphere under RCP $2.5\left(1{ }^{\circ} \mathrm{C}\right.$ increase in global mean air temperature with stringent GHG mitigation), to as much as $26.3 \mathrm{Pg} \mathrm{C}$ under RCP $8.5\left(4^{\circ} \mathrm{C}\right.$ increase in global mean air temperature with very high GHG emissions). By considering only the top $5 \mathrm{~cm}$ soil layer, the loss of SOC 


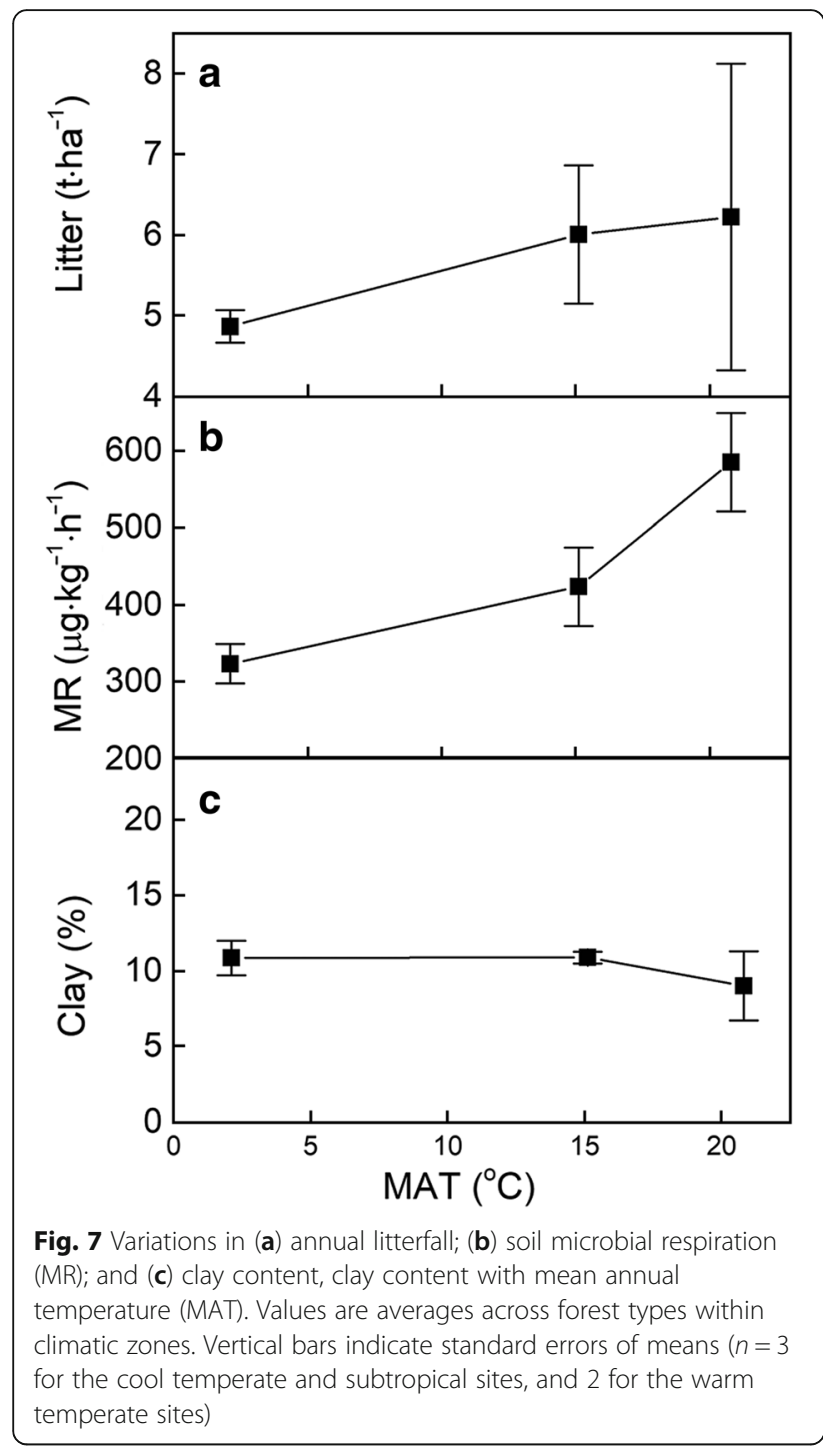

would range from $2.87 \mathrm{Pg} \mathrm{C}$ under RCP 2.5 to $11.5 \mathrm{Pg} \mathrm{C}$ under RCP 8.5.

By any means of accounting, the contribution of forest soils to the atmosphere resulting from warming would likely outweigh the current terrestrial plant uptake from forest regrowth. A marked shift in carbon balance between forest ecosystems and the atmosphere would impose positive feedback to global climate change. Our overall findings raise a key issue of consideration in managing forests for carbon sequestration, and highlight the need in technological development for stabilizing forest SOC with changing climate.

\section{Conclusion}

We assessed the long-term effects of temperature, litter inputs, soil characteristics and vegetation type on the SOC content of the $0-20 \mathrm{~cm}$ soil layer and its fractions across three wet forested sites of contrasting climatic zones in China. The total forest SOC in the $0-20 \mathrm{~cm}$ soil declined with increasing MAT, and annual litterfall and soil microbial respiration increased with increasing MAT. A preferential preservation of $\mathrm{C}$ compounds of higher stability with warmer climate was found, and this might be caused by easily decomposed labile SOC and accumulated recalcitrant SOC components with increasing temperature. We found no apparent effects of forest type on the total SOC and its physical fractions and chemical groups, and only the effective Fe displayed a similar trend as the proportion of alkyl $\mathrm{C}$ and the A/O-A value with MAT.

\section{Abbreviations \\ ${ }^{13} \mathrm{C}$-CPMAS NMR: Solid-state ${ }^{13} \mathrm{C}$ cross-polarization nuclear magnetic reson- ance; A/O-A: The ratio of alkyl $C$ to the sum of O-alkyl $C$ and acetal $C$; C: Carbon; CEC: Cation exchange capacity; ICP-AES: Inductively coupled plasma atomic emission spectrometry; MAP: Mean annual precipitation; MAT: Mean annual temperature; MR: Soil microbial respiration; MRT: Mean residue time; OC: Organic carbon; POM: Particle organic matter; SOC: Soil organic carbon; STN: Soil total nitrogen content}

\section{Acknowledgements}

$X$. Sun acknowledges the financial support of the China Scholarship Council for academic exchange in USA. We thank the Changbai Mountain Forest Ecosystem Research Station, Baotianman Long-Term Forest Ecosystem Research Station, Dinghushan Forest Ecosystem Research Station and Institute of Chemistry Chinese Academy of Sciences for access to the study sites, logistic assistance and sample analyze, and we thank the Institute of Chemistry Chinese Academy of Sciences for helping with the NMR analyze.

\section{Funding}

This study was supported by the National Natural Science Foundation of China (Grant No. 31470623) and the National Basic Research Program of China (Grant No.2011CB403205).

\section{Availability of data and materials}

Available on request.

\section{Authors' contributions}

OJS and XS designed the research. Data were collected and analyzed by XS, ZT and YY. Manuscript was prepared by MGR, OJS and XS. All authors read and approved the final manuscript.

\section{Ethics approval and consent to participate}

Not Applicable.

\section{Consent for publication}

Not Applicable.

\section{Competing interests}

The authors declare that they have no competing interests.

\section{Author details}

${ }^{1}$ College of Forest Science, Beijing Forestry University, Beijing 100083, China. ${ }^{2}$ Institute of Forestry and Climate Change Research, Beijing Forestry University, Beijing 100083, China. ${ }^{3}$ Natural Resource Ecology Laboratory, Department of Ecosystem Science and Sustainability, Colorado State University, Fort Collins CO 80523-1499, USA. ${ }^{4}$ Rocky Mountain Research Station, USDA Forest Service, Fort Collins CO 80526, USA. ${ }^{5}$ College of Forestry, Guangxi University, Nanning 530004, Guangxi, China. 
Received: 19 September 2018 Accepted: 7 January 2019

\section{Published online: 24 January 2019}

\section{References}

Baldock JA, Oades JM, Vassallo AM, Wilson MA (1990) Significance of microbial activity in soils as demonstrated by solid-state ${ }^{13} \mathrm{C}$ NMR. Environ Sci Technol 24:527-530

Bird M, Santrùcková H, Lloyd J, Lawson E (2002) The isotopic composition of soil organic carbon on a north - south transect in western Canada. Eur J Soil Sc 53:393-403

Bradford MA, Wieder WR, Bonan GB, Fierer N, Raymond PA, Crowther TW (2016) Managing uncertainty in soil carbon feedbacks to climate change. Nat Clim Chang 6:751-758

Castellano MJ, Mueller KE, Olk DC, Sawyer JE, Six J (2015) Integrating plant litter quality, soil organic matter stabilization and the carbon saturation concept. Glob Change Biol 21:3200-3209

Chenu C, Stotzky G (2002) Interactions between microorganisms and soil particles: an overview. In: Huang PM, Bollag JM, Senesi N (eds) Interactions between Soil Particles and Microorganisms. John Wiley and Sons, Hoboken New Jersey

Christensen BT (2001) Physical fractionation of soil and structural and functional complexity in organic matter turnover. Eur J Soil Sci 52:345-353

Conant RT, Ryan MG, Ågren GI, Birge HE, Davidson EA, Eliasson PE, Evans SE, Frey SD, Giardina CP, Hopkins FM, Hyvönen R, Kirschbaum MUF, Lavallee JM, Leifeld J, Parton WJ, Steinweg JM, Wallenstein MD, Wetterstedt JÅM, Bradford MA (2011) Temperature and soil organic matter decomposition rates synthesis of current knowledge and a way forward. Glob Change Biol 17: 3392-3404

Conen F, Leifeld J, Seth B, Alewell C (2006) Warming mobilises young and old soil carbon equally. Biogeosciences 3:515-519

Conte P, Piccolo A, van Lagen B, Buurman P, Hemminga MA (2002) Elemental quantitation of natural organic matter by CPMAS ${ }^{13} \mathrm{C}$ NMR spectroscopy. Solid State Nucl Mag 21:158-170

Courtier-Murias D, Simpson AJ, Marzadori C, Baldoni G, Ciavatta C, Fernández JM, López-de-Sá EG, Plaza C (2013) Unraveling the long-term stabilization mechanisms of organic materials in soils by physical fractionation and NMR spectroscopy. Agric Ecosyst Environ 171:9-18

Davidson EA, Janssens IA (2006) Temperature sensitivity of soil carbon decomposition and feedbacks to climate change. Nature 440:165-173

Derenne S, Largeau C (2001) A review of some important families of refractory macromolecules: composition, origin, and fate in soils and sediments. Soil Sci 166:833-847

Du B, Kang H, Pumpanen J, Zhu P, Yin S, Zou Q, Wang Z, Kong F, Liu C (2014) Soil organic carbon stock and chemical composition along an altitude gradient in the Lushan Mountain, subtropical China. Ecol Res 29:433-439

Dungait JAJ, Hopkins DW, Gregory AS, Whitmore AP (2012) Soil organic matter turnover is governed by accessibility not recalcitrance. Glob Change Biol 18: $1781-1796$

Eusterhues K, Rumpel C, Kleber M, Kögel-Knabner I (2003) Stabilisation of soil organic matter by interactions with minerals as revealed by mineral dissolution and oxidative degradation. Org Geochem 34:1591-1600

Fang C, Smith P, Moncrieff JB, Smith JU (2005) Similar response of labile and resistant soil organic matter pools to changes in temperature. Nature 433:57-59

Fierer N, Craine JM, McLauchlan K, Schimel JP (2005) Litter quality and the temperature sensitivity of decomposition. Ecology 86:320-326

Fissore C, Giardina CP, Kolka RK, Trettin CC, King GM, Jurgensen MF, Barton CD, McDowell SD (2008) Temperature and vegetation effects on soil organic carbon quality along a forested mean annual temperature gradient in North America. Glob Change Biol 14:193-205

Fissore C, Giardina CP, Swanston CW, King GM, Kolka RK (2009) Variable temperature sensitivity of soil organic carbon in north American forests. Glob Change Biol 15:2295-2310

Garten CT (2011) Comparison of forest soil carbon dynamics at five sites along a latitudinal gradient. Geoderma 167:30-40

Garten CT, Hanson PJ (2006) Measured forest soil C stocks and estimated turnover times along an elevation gradient. Geoderma 136:342-352

Giardina CP, Ryan MG (2000) Evidence that decomposition rates of organic carbon in mineral soil do not vary with temperature. Nature 404:858-861

Golchin A, Oades JM, Skjemstad JO, Clarke P (1994) Study of free and occluded particulate organic matter in soils by solid state ${ }^{13} \mathrm{C} C \mathrm{CP} / \mathrm{MAS}$ NMR spectroscopy and scanning electron microscopy. Aust J Soil Res 32:285-309
Gupta WSR, Germida JJ (2015) Soil aggregation: influence on microbial biomass and implications for biological processes. Soil Biol Biochem 80:A3-A9

Hakkenberg R, Churkina G, Rodeghiero M, Börner A, Steinhof A, Cescatti A (2008) Temperature sensitivity of the turnover times of soil organic matter in forests. Ecol Appl 18:119-131

Hu Y, Yao X, Liu Y (2014) N and P stoichiometric traits of plant and soil in different forest succession stages in Changbai Mountains. Chin J Appl Ecol 25:632-638. doi:https://doi.org/10.13287/j.1001-9332.2014.0034 (in Chinese with English abstract)

Jastrow JD, Miller RM (1997) Soil aggregate stabilization and carbon sequestration: feedbacks through organomineral associations. In: Lal R, Kimble JM, Follett RF (eds) Soil processes and the carbon cycle. CRC press, Boca Raton, Florida

Jobbágy EG, Jackson RB (2000) The vertical distribution of soil organic carbon and its relation to climate and vegetation. Ecol Appl 10:423-436

Johnson K, Purvis G, Lopez-Capel E, Peacock C, Gray N, Wagner T, März C, Bowen L, Ojeda J, Finlay N, Robertson S, Worrall F, Greenwell C (2015) Towards a mechanistic understanding of carbon stabilization in manganese oxides. Nat Commun. https://doi.org/10.1038/ncomms8628

Jones E, Singh B (2014) Organo-mineral interactions in contrasting soils under natural vegetation. Front Environ Sci. https://doi.org/10.3389/fenvs.2015.00083

Kleber M (2010) What is recalcitrant soil organic matter. Soil Biol Biochem 42: $529-535$

Knicker H (2011) Pyrogenic organic matter in soil: its origin and occurrence, its chemistry and survival in soil environments. Quat Int 243:251-263

Kögel-Knabner I (1997) ${ }^{13} \mathrm{C}$ and ${ }^{15} \mathrm{~N}-\mathrm{NMR}$ spectroscopy as a tool in soil organic matter studies. Geoderma 80:243-270

Kögel-Knabner I, Guggenberger G, Kleber M, Kandeler E, Kalbitz K, Scheu S, Eusterhues K, Leinweber P (2008) Organo-mineral associations in temperate soils: integrating biology, mineralogy, and organic matter chemistry. J Plant Nutr Soil Sci 171:61-82

Krull ES, Skjemstad JO (2003) $\delta^{13} \mathrm{C}$ and $\delta^{15} \mathrm{~N}$ profiles in ${ }^{14} \mathrm{C}$-dated Oxisol and Vertisols as a function of soil chemistry and mineralogy. Geoderma 112:1-29

Lal R (2005) Forest soils and carbon sequestration. Forest Ecol Manag 220:242-258

Liu Y, Han SJ, Lu L (2009) Seasonal changes of soil respiration in Betula platyphylla forest in Changbai Mountain, China. J For Res 20:367-371

Lützow MV, Kögel-Knabner I, Ekschmitt K, Flessa H, Guggenberger G, Matzner E, Marschner B (2007) SOM fractionation methods: relevance to functional pools and to stabilization mechanisms. Soil Biol Biochem 39:2183-2207

Lützow MV, Kögel-Knabner I, Ekschmitt K, Matzner E, Guggenberger G, Marschner B, Flessa H (2006) Stabilization of organic matter in temperate soils: mechanisms and their relevance under different soil conditions - a review. Eur J Soil Sci 57:426-445

Mathieu JA, Hattt C, Balesdent J, Parent É (2015) Deep soil carbon dynamics are driven more by soil type than by climate: a worldwide meta-analysis of radiocarbon profiles. Glob Chang Biol 21:4278-4292

Mayer LM (2004) The inertness of being organic. Mar Chem 92:135-140

Mikutta R, Kleber M, Torn MS, Jahn R (2005) Review: organic matter removal from soils using hydrogen eroxide, sodium hypochlorite. and disodium peroxodisulfate Soil Sci Soc Am J 69:120-135

Mikutta R, Kleber M, Torn MS, Jahn R (2006) Stabilization of soil organic matter: association with minerals or chemical recalcitrance? Biogeochemistry 77:25-56

Mo J, Xue J, Fang $Y$ (2004) Litter decomposition and its responses to simulated $\mathrm{N}$ deposition for the major plants of Dinghushan forests in subtropical China. Chin J Ecol 24:1413-1420. doi:1000-0933(2004) 07-1413-08 (in Chinese with English abstract)

Motavalli PP, Palm CA, Parton WJ, Elliott ET, Frey SD (1994) Comparison of laboratory and modeling simulation methods for estimating soil carbon pools in tropical forest soils. Soil Biol Biochem 26:935-944

Nelson DW, Sommers LE (1982) Total carbon, organic carbon, and organic matter. In: Page AL, Miller RH, Keeney DR (eds) Methods of Soil Analysis. Part 2. Chemical and Microbiological Properties, American Society of Agronomy, Madison, Wisconsin

Oades JM (1995) An overview of processes affecting the cycling of organic carbon in soils. In: Zepp RG, Sonntag C (eds) The Role of Nonliving Soil Organic Matter in The Earth's Carbon Cycling. John Wiley \& Sons, Chichester

Paul EA (2016) The nature and dynamics of soil organic matter: plant inputs, microbial transformations, and organic matter stabilization. Soil Biol Biochem 98:109-126

Pignatello JJ (1999) The measurement and interpretation of sorption and desorption rates for organic compounds in soil media. Adv Agron 69:1-73

Pisani O, Hills KM, Courtier-Murias D, Haddix ML, Paul EA, Conant RT, Simpson AJ, Arhonditsis GB, Simpson MJ (2014) Accumulation of aliphatic compounds in soil with increasing mean annual temperature. Org Geochem 76:118-127 
Pisani O, Hills KM, Courtier-Murias D, Simpson AJ, Mellor NJ, Paul EA, Morris SJ, Simpson MJ (2013) Molecular level analysis of long term vegetative shifts and relationships to soil organic matter composition. Org Geochem 62:7-16

Plante AF, Conant RT, Stewart CE, Paustian K, Six J (2006) Impact of soil texture on the distribution of soil organic matter in physical and chemical fractions. Soil Sci Soc Am J 70:287-296

Plante AF, Six J, Paul EA, Conant RT (2009) Does physical protection of soil organic matter attenuate temperature sensitivity? Soil Sci Soc Am J 73:1168-1172

Poeplau C, Don A, Dondini M, Leifeld J, Nemo R, Schumacher J, Senapati N, Wiesmeier M (2013) Reproducibility of a soil organic carbon fractionation method to derive RothC carbon pools. Eur J Soil Sci 64:735-746

Prescott CE, Zabek LM, Staley CL, Kabzems R (2000) Decomposition of broadleaf and needle litter in forests of British Columbia: influences of litter type, forest type, and litter mixtures. Can J For Res 30:1742-1750

Quideau SA, Chadwick OA, Trumbore SE, Johnson-Maynard JL, Graham RC, Anderson MA (2001) Vegetation control on soil organic matter dynamics. Org Geochem 32:247-252

Raich JW, Russell AE, Kitayama K, Parton WJ, Vitousek PM (2006) Temperature influences carbon accumulation in moist tropical forests. Ecology 87:76-87

Schmidt MWI, Knicker H, Hatcher PG, Kogel-Knabner I (1997) Improvement of ${ }^{13} \mathrm{C}$ and ${ }^{15} \mathrm{~N}$ CPMAS NMR spectra of bulk soils, particle size fractions and organic material by treatment with 10\% hydrofluoric acid. Eur J Soil Sci 48:319-328

Schmidt MWI, Torn MS, Abiven S, Dittmar T, Guggenberger G, Janssens IA, Kleber M, Kögel-Knabner I, Lehmann J, Manning DAC, Nannipieri P, Rasse DP, Weiner S, Trumbore SE (2011) Persistence of soil organic matter as an ecosystem property. Nature 478:49-56

Six J, Bossuyt H, Degryze S, Denef K (2004) A history of research on the link between (micro) aggregates, soil biota, and soil organic matter dynamics. Soil Tillage Res 79:7-31

Six J, Callewaert P, Lenders S, De Gryze S, Morris SJ, Gregorich EG, Paul EA, Paustian K (2002a) Measuring and understanding carbon storage in afforested soils by physical fractionation. Soil Sci Soc Am J 66:1981-1987

Six J, Feller C, Denef K, Ogle S, de Moraes Sa JC, Albrecht A (2002b) Soil organic matter, biota and aggregation in temperate and tropical soils-effects of notillage. Agronomie 22:755-775

Skjemstad JO, Clarke P, Taylor JA, Oades JM, McClure SG (1996) The chemistry and nature of protected carbon in soil. Aust J Soil Res 34:251-271

Skjemstad JO, Dalal RC (1987) Spectroscopic and chemical differences in organic matter of two Vertisols subjected to long periods of cultivation. Aust J Soil Res 25:323-335

Skjemstad JO, Frost RL, Barron PF (1983) Structural units in humic acids in SouthEastern Queensland soils as determined by ${ }^{13} \mathrm{C}-\mathrm{NMR}$ spectroscopy. Aust J Soil Res 21:539-547

Smith JU, Smith P, Monaghan R, MacDonald AJ (2002) When is a measured soil organic matter fraction equivalent to a model pool? Eur J Soil Sci 53:405-416

Smith P, Fang C, Dawson JJ, Moncrieff JB (2008) Impact of global warming on soil organic carbon. Adv Agron 97:1-43

Sollins P, Homann P, Caldwell BA (1996) Stabilization and destabilization of soil organic matter: mechanisms and controls. Geoderma 74:65-105

Sollins P, Swanston C, Kleber M, Filley T, Kramer M, Crow S, Caldwell BA, Lajtha K, Bowden R (2006) Organic C and N stabilization in a forest soil: evidence from sequential density fractionation. Soil Biol Biochem 38:3313-3324

Stockmann U, Adams MA, Crawford JW, Field DJ, Henakaarchchi N, Jenkins M, Minasny B, McBratney AB, de Courcelles VR, Singh K, Wheeler I, Abbott L, Angers DA, Baldock J, Bird M, Brookes PC, Chenu C, Jastrow JD, Lal R, Lehmann J, O'Donnell AG, Parton WJ, Whiteheadm D, Zimmermann M (2013) The knowns, known unknowns and unknowns of sequestration of soil organic carbon. Agric Ecosyst Environ 164:80-99

Tang Z, Sun X, Luo Z, He N, Sun OJ (2018) Effects of temperature, soil substrate, and microbial community on carbon mineralization across three climatically contrasting forest sites. Ecol Evol 8:879-891

ten Hulscher TEM, Cornelissen G (1996) Effect of temperature on sorption equilibrium and sorption kinetics of organic micropollutants - a review. Chemosphere 32:609-626

Tian Q, He H, Cheng W, Bai Z, Wang Y, Zhang XD (2016) Factors controlling soil organic carbon stability along a temperate forest altitudinal gradient. Sci Rep 6:18783. https://doi.org/10.1038/srep18783

Trumbore SE, Chadwick OA, Amundson R (1996) Rapid exchange between soil carbon and atmospheric carbon dioxide driven by temperature change. Science 272:393-396

Wagai R, Mayer LM, Kitayama K (2009) Nature of the "occluded" low-density fraction in soil organic matter studies: a critical review. Soil Sci Plant Nutr 55:13-25
Wang H, Liu SR, Mo JM, Wang JX, Makeschin F, Wolff M (2010) Soil organic carbon stock and chemical composition in four plantations of indigenous tree species in subtropical China. Ecol Res 25:1071-1079

Wang J, You Y, Tang Z, Sun OJ (2015) Variations in leaf litter decomposition across contrasting forest stands and controlling factors at local scale. J Plant Ecol 8:261-272

Wang J, You Y, Tang Z, Sun X, Sun OJ (2016) A comparison of decomposition dynamics among green tree leaves, partially decomposed tree leaf litter and their mixture in a warm temperate forest ecosystem. J Forestry Res 27:1037-1045

Wang M, Li QR, Xiao DM, Dong BL (2004) Effects of soil temperature and soil water content on soil respiration in three forest types in Changbai Mountain. J For Res 15:113-118

Watson RT, Noble IR, Bolin B, Ravindranath NH, Verardo DJ, Dokken DJ (2000) Land Use, Land-Use Change, and Forestry. Cambridge University Press, Cambrige, UK

Wen D, Kong G, Wei P, Zhang Y (1998) Dry mass loss and chemical changes of the decomposed fine roots in three China south subtropical forests at Dinghushan. Chin J Ecol 17:1-6. doi:https://doi.org/10.13292/j.1000-4890. 1998.0016 (in Chinese with English abstract)

Yan J, Zhou G, Tang X, Zhang D (2001) Characteristics of litter and its contained water in three succession communities in Dinghushan Mountain. Chin J Appl Ecol 12:509-512. doi:https://doi.org/10.13287/j.1001-9332.2001.0121 (in Chinese with English abstract)

Yang LY, Wu ST, Zhang LB (2010) Fine root biomass dynamics and carbon storage along a successional gradient in Changbai Mountains, China. Forestry 83:379-387

You Y, Wang J, Huang X, Tang Z, Liu S, Sun OJ (2014) Relating microbial community structure to functioning in forest soil organic carbon transformation and turnover. Ecol Evol 4:633-647

You Y, Wang J, Sun X, Tang Z, Zhou Z, Sun OJ (2016) Differential controls on soil carbon density and mineralization among contrasting forest types in a temperate forest ecosystem. Sci Rep 6:22411. https://doi.org/10.1038/ srep22411

Zhang H, Zhou Z (2018) Recalcitrant carbon controls the magnitude of soil organic matter mineralization in temperate forests of northern China. Forest Ecosyst 5:17. https://doi.org/10.1186/s40663-018-0137-z

Zhang Q, Han R, Huang Z, Zou F (2013) Linking vegetation structure and bird organization: response of mixed-species bird flocks to forest succession in subtropical China. Biodivers Conserv 22:1965-1989

Zhao J, Guo J, Xu J, Mao F, Yang X, Zhang Y (2010) Trends of Chinese dry-wet condition based on wetness index. Transactions of the CSAE 26:18-24 (in Chinese with English abstract)

Zheng JP, Guo ZL, Xu CY, Fan CN (2011) Seasonal dynamics of litter accumulation in major forest communities on the northern slope of Changbai Mountain, Northeast China Chin J Ecol 31:4299-4307. doi: https://doi.org/10.3969/j.issn. 1002-6819.2010.08.003 (in Chinese with English abstract)

Zhou C, Zhou G, Zhang D, Wang Y, Liu S (2005) $\mathrm{CO}_{2}$ efflux from different forest soils and impact factors in Dinghu Mountain. China Sci China Earth Sci 48: 198-206

Ziegler S, Benner R, Billings S, Edwards K, Philben M, Zhu X, Laganiere J (2017) Climate warming can accelerate carbon fluxes without changing soil carbon stocks. Front Earth Sci 5:2. https://doi.org/10.3389/feart.2017.00002

Zimmermann M, Meir P, Silman MR, Fedders A, Gibbon A, Malhi Y, Urrego DH, Bush MB, Feeley K, Garcia KC, Dargie GC, Farfan WR, Goetz BP, Johnson WT, Kline KM, Modi AT, Rurau NMQ, Staudt BT, Zamora F (2010) No differences in soil carbon stocks across the tree line in the Peruvian Andes. Ecosystems 13:62-74 